DOI: 10.17234/SRAZ.65.39

UDK: 811.13-05 Niculescu, A.

Primit la 1 mai 2020

Acceptat pentru publicare la 25 noiembrie 2020

\title{
Memorialistica unui profesor romanist - Alexandru Niculescu
}

\author{
Elena-Camelia Zăbavă \\ Institutul Limbii Române \\ Universitatea din Craiova \\ Universitatea "Sfinții Chiril și Metodiu” Veliko Tărnovo \\ cameliazabava@yahoo.com
}

\begin{abstract}
Alexandru Niculescu a fost profesor la Facultatea de Litere din București, profesor invitat la universitățile din Viena (1963-1965), Padova (1965-1971), Sorbona (1980-1993) și Udine (1986-2000). Din anul 1983 trăiește în exil, fiind refugiat politic în Franța. De asemenea, a fost vicepreședinte al Societății Române de Lingvistică Romanică. În afara studiilor științifice (Originile limbilor neolatine, 1977; Individualitatea limbii române între limbile romanice, vol I, 1965, vol. II, 1978), Alexandru Niculescu a scris și memorialistică.

Ne ocupăm în lucrarea de față de volumul său de memorii Peregrinări universitare europene - şi nu numai, apărut la editura bucureşteană Logos, în 2010.

Cartea este structurată în capitole care au ca titlu numele unor oraşe universitare şi reînvie figuri emblematice ale lingvisticii româneşti: Alexandru Rosetti, Iorgu Iordan, Boris Cazacu, alături de personalități cunoscute de la marile universităţi europene: $C$. Th. Gossen (Viena), Gianfranco Folena (Padova), Maurice Molho (Paris). Al. Niculescu creionează și portretele unor cunoscuți lingviști de origine română din exil cum ar fi: Eugen Coșeriu, Gheorghe Caragață, Eugen Lozovan, Alexandrina Mititelu și alții. Dincolo de informațiile de ordin lingvistic, istoric și cultural pe care le oferă volumul semnat de Alexandru Niculescu, trebuie remarcat stilul scriiturii, valențele literare fiind date de formula narativă și de arta portretului, realizat într-o expunere sobră, esenţială. Dintre toate, se distinge cel al lui Roman Jakobson.
\end{abstract}

Cuvinte cheie: memorialistică, profesor, lingvistică, limbi romanice, universități

\section{Introducere}

În Cuvântul înainte la volumul Memorialistica românească: între documentul istoric și obiectul estetic, Bogdan Crețu (2017: 7) susține următoarea idee:

„Discursul memorialistic nu ascultă de reguli, chiar dacă nu puţine eforturi teoretice au încercat să îi ofere o structură. În plus, operele care valorifică diferitele tipuri de memorie obligă la o hermeneutică laborioasă, interdisciplinară. Interpretarea strict estetică nu este, în mod clar, suficientă. 
Nu întâmplător, aceste opere sunt frecventate de istorici, de istorici literari, de antropologi, de istorici ai artelor. Prin urmare, deschiderea către alte domenii este obligatorie".

În galeria autorilor de scrieri memorialistice prezentată de cercetătorul ieșean, ne îngăduim să-i adăugăm și pe lingviști, pentru că nu puține sunt cazurile în care specialiștii în lingvistică au creat remarcabile pagini de memorialistică cu valoare documentară, instructive în același timp, dar și literară, distrugând astfel ideea că lingviștii scriu arid, iar scrierile lor nu pot fi compatibile cu literatura. (Zăbavă 2016: 46)

Sextil Puşcariu, Iorgu Iordan, Alexandru Rosetti, Tatiana Slama-Cazacu, Sanda Golopenția-Eretescu, Marius Sala sunt doar câteva exemple de mari lingviști și profesori români care au dat culturii noastre opere situate la granița dintre documentul istoric și actul estetic, adevărate cursuri interdisciplinare, cărora nu le lipsește nici bibliografia savantă, dar nici latura umană, pentru că ele sunt scrise într-un timp al amintirilor, al retrăirilor, al autoanalizei.

Vorbind despre volumul lui Al. Niculescu, Peregrinări universitare europene -și nu numai -, Iulia Mărgărit (2010: 191) observa că acesta se situează la granița dintre memorialistică și amintiri, dintre lingvistică și beletristică, autorul însuși ezitând în alegerea termenilor: „paginile precedente [...] se numesc - de obicei memorii. Prefer să evit acest incolor termen și să le numesc sinonimic, amintiri despre oameni, fapte [...] - mai ales gânduri post actum [...]. Sunt uneori veritabile confesiuni" (Niculescu 2010: 374).

Născut la Craiova în 1928, Alexandru Niculescu a fost profesor de lingvistică la Universitatea din București și în mai multe universități din lume: Universitatea din Viena, la Universitatea din Padova, la Universitatea Sorbona - Paris IV și la Universitatea din Udine. Principalele sale lucrări analizează evoluția și structura limbii române în comparație cu celelalte limbi romanice, ceea ce lingviștii români numeau locul limbii române printre limbile romanice, continuând munca și ideile remarcabililor săi înaintași, Sextil Pușcariu, Alexandru Rosetti, Iorgu Iordan. Ceea ce l-a preocupat pe Al. Niculescu în întreaga sa carieră de profesor și cercetător al limbii a fost Individualitatea limbii române printre limbile romanice, lucrare care a apărut în patru volume (1965, 1978, 1999, 2004).

\section{Un profesor romanist în universităţi europene}

Volumul Peregrinări universitare europene -și nu numai- este, așa cum însuși autorul mărturisește, o poveste, povestea vieții sale „,active, universitare”, , care a început la 14 ianuarie 1950 la București, în România, și s-a încheiat în anul 2002, în Italia, la Udine. Între aceste două puncte bine delimitate ab initio, cariera de profesor a lui Alexandru Niculescu s-a desfășurat în mai multe universități europene: București, Viena, Paris, Padova, Humbold, în Berlinul de Est, Udine, suprapunându-se uneori și intercalându-se alteori cu evenimente personale și, nu în ultimul rând, cu un exil politic în Franţa în 1985.

Cartea poate fi privită ca un Bildungsroman, pentru că prezintă un drum de inițiere, formarea unui profesor romanist, începând cu debutul în carieră - 
numirea ca preparator la Catedra de istorie a limbii române a Universității din București. În primul capitol autorul marchează momentele cheie din cariera sa bucureșteană: mutarea la Catedra de lingvistică romanică sub conducerea lui Iorgu Iordan în 1957; participarea la Cursurile de vară de la Sinaia, organizate de Universitatea din București, prilej cu care cunoaște o serie de personalități europene printre care: André Martinet, C. Th. Gossen, Carlo Tagliavini, Rosa Del Conte, Antoine Adam, Lorenzo Renzi; relația dintre profesorul Iorgu Iordan și fostul său student, contradicțiile de metodologie în domeniul romanisticii care interveniseră între cei doi. Preocupările lingvistice ale tânărului Al. Niculescu se canalizaseră deja pe studierea limbilor romanice și a limbii române în acest context, evidențiind particularitățile gramaticale românești în cadrul romanității. Primele două volume din Individualitatea limbii române printre limbile romanice pun în discuție „fenomene largi, evoluții istorice, culturale, sociale, trecând dincolo de limitele structurilor stricte ale limbii române". (Niculescu 2010: 24) Lingvistul studiază româna din perspectiva ansamblului comparativ al limbilor romanice, altfel spus, studiază romanitatea românească (conceptul îi aparține). Următoarea etapă în cariera profesorului o reprezintă experiența trăită, ca lector de limba română, la Universitatea berlineză din Est (martie - iulie 1955). După moartea lui I. V. Stalin are loc o deschidere a României către Europa, începând cu universitățile din țările socialiste. Datorită acestor deschideri, Alexandru Niculescu se regăsește printre primii lectori de limba română care vor preda într-o universitate străină. Experiența trăită la Universitatea Humboldt nu este foarte plăcută pentru tânărul profesor; atmosfera apăsătoare, starea instituției, „lipsa oricărei emulații științifice (de lingvistică nici nu era vorba), o simplă cursă după cariere universitare, cu sprijin politic". (Niculescu 2010:53) îl fac să renunțe la acest post. Marele avantaj pe care îl găsește la universitatea berlineză este biblioteca înzestrată cu volume apărute în Occident, dar și cu publicații periodice de lingvistică și filologie romanică.

Următorul popas în peregrinările universitare ale tânărului romanist va fi la Viena (1963-1965) unde ajunge ca „Gastprofessor", susținut de Iorgu Iordan și invitat de Carl Theodor Gossen, pe care îl cunoscuse la Sinaia. La universitatea vieneză îl va cunoaște pe Lorenzo Renzi, lectorul de limbă italiană, cu care va lega o puternică și durabilă prietenie academică. La Viena cunoaște personalități ale lumii științifice europene, invitate de Gossen să țină conferințe (printre aceștia și pe Eugen Coșeriu care venise de la Tübingen), și primește, în același scop, invitații la München și la Padova.

Din 1965 până în 1971 Alexandru Niculescu este professore incaricato, la Universitatea din Padova. Este o perioadă importantă în formarea sa profesională, el însuși afirmând că „Padova a constituit pentru mine o adevărată școală în care mi-am format și rectificat cunoștințele politice-culturale românești" (Niculescu 2010: 119). Padova îi dă posibilitatea să studieze românitatea în centrul romanității; este universitatea care îi oferă tânărului romanist numeroase avantaje profesionale: posibilitatea de a participa la cercul de studii al lui Gianfranco Folena, șansa de a adera la „,Societatea de Lingvistică Italiană”, condusă de Tullio de Mauro, deschiderea unor noi orizonturi de specialitate, contacte directe cu 
valoroși lingviști și filologi ai acelor vremuri: Giacomo Devoto, Gh. Caragață, B. Migliorini, G. Nencioni, G. Contini, Th. Onciulescu, R. Jakobson.

„Aventura" universitară continuă; începând cu anul 1980 îl vom regăsi profesor de limba română în capitala Franței, la Sorbona. De perioada pariziană este legată realizarea celor trei volume omagiale Studi rumeni e romanzi. Omaggio a Florica Dimitrescu e Alexandru Niculescu (Padova, 1995), pe baza unor colaborări din Padova, Udine, Timișoara, Cracovia, București, Roma, Potenza, Paris, Cluj, Bloomington (USA), Glensdale (USA), prin efortul profesorilor Lorenzo Renzi (Padova) și Coman Lupu (București).

Între anii 1986 și 2002 Al. Niculescu este professor titular la Universitatea din Udine. Aici înființează „Associazione Italiana dei Romenisti”, cu scopul de a reprezenta limba română în Italia și în Occident și de a forma o generație nouă de româniști. La ora bilanțului, activitatea sa în mediul universitar udinez este evaluată obiectiv: „,nu mi-am putut crea o școală științifică de româniști la Udine. Dar [...] am format o echipă de buni cunoscători ai limbii și culturii noastre" (Niculescu 2010: 345). Acesta avea să fie punctual terminus al activității sale profesorale. Întors la București, își va continua activitatea științifică.

\section{Arta scrisului}

Relația dintre titlu și conținutul cărții este una directă. Presupunând că nu se cunoaște autorul, titlul lasă să se înțeleagă că este vorba despre viața universitară, aceste peregrinări nefiind altceva decât etape în formarea personalității unui profesor romanist, despre ale cărui preocupări științifice aflăm din primele pagini ale cărții.

Remarcăm apoi construcția echilibrată, circulară a cărții: primul capitol Incipit vita nova precum și ultimele Finis scribendi, Post scriptum sunt oarecum în afara titlului, ele reflectă o perioadă de stabilitate, primul corespunzând debutului în viața universitară, cele din urmă - perioadei așezate a bilanțului. Între cele două puncte fixe încep peregrinările.

Îl regăsim aici pe Alexandru Niculescu în poziția cronicarului care dă seamă de toate cele scrise și întâmplate de-a lungul vieții sale universitare și nu numai. Și o face sub forma unui curs amplu, cu delicate note de confesiune, cu bogate trimiteri biografice și bibliografice, dezvăluindu-ne încă o data Profesorul.

Chiar dacă nu și-a propus să facă din istoria acestor peregrinări literatură, volumul pe care ni-l oferă - prin construcție, tematică (bildungsroman), fir narativ, portretistică - are reale valențe literare.

S-a observant că lingviștii au un talent aparte în arta portretului. Sextil Pușcariu, Marius Sala, Sanda Golopenția și Alexandru Niculescu, sunt autorii unor memorabile portrete ale unor personalități cu care au interacționat și care le-au influențat viața și cariera.

Cu o permanentă pendulare între abordarea subiectivă și cea obiectivă, sunt creionate portretele marilor săi profesori, Alexandru Rosetti și Iorgu Iordan. După cum remarca și Iulia Mărgărit, portretele „sunt realizate din câteva trăsături 
morale și fizice, într-o expunere sobră, esențială".(2010: 195)

Dar, dintre toate figurile evocate de Al. Niculescu, se desprinde imaginea lui Roman Jakobson, al cărui portret este creionat cu fină observație, reușind să reliefeze calitățile unice ale acestui colos al lingvisticii:

„Mi-a părut atunci, acest om de geniu (îmi cumpănesc bine cuvintele!) care se sprijinea anxios, pe brațul meu stâng, un legendar patriarh oriental, un Rus în exil, un mare evreu rătăcitor într-o lume străină, indiferentă, care nu-i percepea genialitatea. Îl asemuiam Albatrosului lui Baudelaire. [...] L-am considerat întotdeauna pe Roman Jakobson un geniu - singurul geniu pe care l-am cunoscut în viaţă. Poate şi cel mai chinuit interior de vâlvătăile existenței sale în exil, dincolo de spațiu şi timp. Precum un legendar Ahasverus, contemporan cu noi, printre noi". (Niculescu 2010: 147)

Fin observator al trăirilor omenești, lui Alexandru Niculescu nu-i scapă neobservată și nu poate rămâne indiferent la tristețea superioară a lui Roman Jakobson; cu atât mai mult cu cât el însuși gustase din amărăciunea exilului. Dar Niculescu nu e singurul lingvist român asupra căruia personalitatea lui R. Jakobson făcuse o impresie puternică. Sanda Golopenția-Eretescu consemnează în volumul Bulevardele vieții momentul reîntâlnirii cu marele lingvist rus, la Cambridge, prilej de a-1 privi într-o altă ipostază, pe care ea însăși o va cunoaște - tăcerea și însingurarea emigrantului „Stătea singur în dreptul unui uriaș bol cu punci, vultur cu aripile frânte, și tăcea opac". (2018:105)

\section{Concluzii}

Volumul Peregrinări universitare europene - și nu numai- este o frescă a vieții universitare (și nu numai!) din București și din mari centre de cultură europene: Viena, Padova, Paris, Udine, dar și a societății acelor vremuri uneori tulburi, alteori liniștite, din perioada 1954-2002. Este povestea unei lungi cariere didactice, de peste jumătate de secol, este experiența de viață a unui lingvist, a unui om care scrie o carte despre nenumărate cărți, idei, personalități, cultură în general, cu luciditatea omului de știință, dar, în aceeași măsură, și cu sufletul. Este o carte a autobilanțului, scrisă cu datoria cronicarului care consemnează fapte și oameni pentru a fi cunoscute și a nu fi uitate.

\section{Bibliografie}

Crețu, Bogdan, Ichim, Ofelia, Clim, Marius-Radu (coord.) (2017). Memorialistica românească: între documentul istoric și obiectul esthetic, Iași: Editura Universității „Alexandru Ioan Cuza".

Golopenția, Sanda (2018). Bulevardele vieții, București: Editura Spandugino.

Mărgărit, Iulia (2010). Niculescu, Alexandru (2010). Peregrinări universitare europene -și nu numai -, București: Editura Logos, 2010, 397p., în Dacoromania, 2, pp. 191-196. 
Niculescu, Alexandru (2010). Peregrinări universitare europene -și nu numai -, București: Editura Logos.

Sala, Marius (2013). Portrete și evocări, Timișoara: Editura David Press Print. Zăbavă, Elena-Camelia (2016). Repere lingvistice și culturale, Craiova: Editura Aius.

\section{Memories of a Professor of Romance Languages - Alexandru Niculescu}

Alexandru Niculescu was a professor at the Faculty of Philology, University of Bucharest, and a visiting professor at other foreign Universities in Vienna (1963-1965), Padova (1965-1971), Sorbonne (1980-1993), and Udine (1986-2000). He was also a vice-president of the Romanian Society of Romance Languages. Since 1983 he chose to live in exile, as a political refugee in France.

Besides scientific books (Originile limbilor neolatinel Origins of the Neo-latin Languages, 1977; Individualitatea limbii române între limbile romanicel The Individuality of the Romanian Language among Romance Languages, vol I, 1965, vol. II, 1978), Alexandru Niculescu published also memories. In our paper we present his volume of memories Peregrinări universitare europene - şi nu numai (European university pilgrimages - and more), published by the Logos Publishing House, Bucharest, 2010.

The philologist describes his itinerary in the scientific training, starting with University of Bucharest and continuing with Berlin, Vienna, Padova, Paris and Udine.

The book is divided into more chapters, each of them having as a title the name of the cities where he studied or worked as a visiting professor.

In many pages the author describes some important Romanian linguists, professors in Bucharest (Alexandru Rosetti, Iorgu Iordan, Boris Cazacu) or some Romanian personalities who lived and taught in exile (Eugeni Coșeriu, Gheorghe Caragață, Eugen Lozovan, Alexandrina Mititelu) and also well-known philologists from different European Universities - C. Th. Gossen (Vienna), Gianfranco Folena (Padova), Maurice Molho (Paris). Thus, besides lots of information regarding linguistics, history or culture the reader can appreciate in Alexandru Niculescu's volume of memories the author's style, the narrative art and also his talent in making portraits. An example among other personalities he describes - Roman Jakobson.

In this volume, Niculescu seems to talk to himself, having his reader as a witness. He highlights some important moments in his university career in Bucharest: in 1957 he was appointed at the Chair of Romance Linguistics (managed by Iorgu Iordan) and participated at the Sumer Courses in Sinaia, an opportunity to meet some European professors such as Rosa del Conte, Carl Theodor Gossen, Carlo Tagliavini, André Martinet.

As a linguist, starting with the first pages, Niculescu writes about his permanent preoccupation to emphasize the main characteristics of the Romanian grammar among the other Romance languages. He studied Romanian, as he confessed, in a comparative ensemble of the Romance languages or, in his terms, he studied Romanian Romanity.

Key words: memories, professor, linguistics, romance languages, universities 